\title{
Rainfall patterns after fire differentially affect the recruitment of three Mediterranean shrubs
}

\author{
J. M. Moreno ${ }^{1}$, E. Zuazua ${ }^{1}$, B. Pérez ${ }^{1}$, B. Luna ${ }^{1}$, A. Velasco ${ }^{1}$, and V. Resco de Dios ${ }^{1, *}$ \\ ${ }^{1}$ Department of Environmental Sciences, University of Castilla-La Mancha, Toledo, Spain \\ *now at: Hawkesbury Institute for the Environment, University of Western Sydney, Richmond, Australia
}

Received: 29 April 2011 - Published in Biogeosciences Discuss.: 21 June 2011

Revised: 25 November 2011 - Accepted: 29 November 2011 - Published: 19 December 2011

\begin{abstract}
In fire-prone environments, the "event-dependent hypothesis" states that plant population changes are driven by the unique set of conditions of a fire (e.g. fire season, climate). Climate variability, in particular changes in rainfall patterns, can be most important for seeder species, since they regenerate after fire from seeds, and for Mediterranean shrublands, given the high yearly variability of rainfall in these ecosystems. Yet, the role of rainfall variability and its interaction with fire characteristics (e.g. fire season) on plant populations has received little attention. Here we investigated the changes in seedling emergence and recruitment of three seeder species (Cistus ladanifer, Erica umbellata and Rosmarinus officinalis) after fires lit during three different years and at two times (early and late) during the fire season. Three plots were burned at each season, for a total of 18 plots burned during the three years. After fire, emerged seedlings were tallied, tagged and monitored during three years (two in the last burning year). Rainfall during the study period was rather variable and, in some years, it was well below average. Postfire seedling emergence varied by a factor of 3 to 12 , depending on the species and on the burning year. The bulk of seedling emergence occurred during the first year after fire; seedling recruitment at the end of the study period was tightly correlated with this early emergence. Emergence in Erica and Rosmarinus, but not in Cistus, was correlated with precipitation in the fall and winter immediately after fire, with Erica being the most sensitive to reduced rainfall. Fire season was generally neither an important factor in controlling emergence nor, in particular, recruitment. We discuss how projected changes in rainfall patterns with global warming could alter the balance of species in this shrubland, and could drive some species to near local extinction.
\end{abstract}

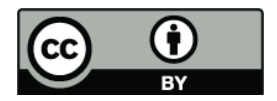

Correspondence to: J. M. Moreno (josem.moreno@uclm.es)

\section{Introduction}

In fire-prone environments, the "event-dependent hypothesis" states that plant population changes are driven by the unique set of conditions of a fire (e.g. fire intensity, fire season, fire area or pre-, and/or post-fire climate; Bond and van Wilgen, 1996). For a given vegetation type, the energy released during fire varies enormously, depending on the weather conditions during fire in interaction with fuel structure and composition (Bessie and Johnson, 1995). Therefore, it is not surprising that much attention has focussed on understanding the role of fire intensity and severity on plant populations (Moreno and Oechel, 1991; Pausas et al., 2003; Keeley et al., 2008). Studies on how fire season affects postfire plant regeneration have also been conducted for a long time (Trabaud and Lepart, 1981) because of its significance for management, amongst other reasons. Yet, our understanding of the role of fire season is limited because few studies have temporal replication (Knox and Clarke, 2006). Thus, the effect of temporal variation in post-fire climate on plant population changes after fire, while potentially important, has only seldom been considered (Keeley et al., 2005). Although some studies have addressed the impact of weather and climate extremes following fire (e.g. droughts, heavy rains) (De Luis et al., 2005; Prieto et al., 2009), little is known about how inter-annual rainfall variability interacts with other components of the fire regime, namely fire season (but see Bradstock and Bedward, 1992), to affect plant regeneration after fire.

The effects of post-fire rainfall and fire season on plant regeneration after fire deserve particular attention in the Mediterranean region and other Mediterranean-type climate areas of the world. These areas are characterized by warm and dry summers, and cool and moist winters; total yearly precipitation as well as the length of the rainy season are highly variable from year to year, and droughts are common (Lana et al., 2006). Fires, particularly very large fires,

Published by Copernicus Publications on behalf of the European Geosciences Union. 
and multiple large fire-episodes tend to occur under severe fire weather, which is partly the result of reduced rainfall and high temperatures (Trigo et al., 2006; Founda and Giannakopoulos, 2009). Therefore, large areas, which at times can amount to significant portions of a country, could be regenerating under, and be subject to, similar climatic conditions. That is, the effects of climate variability on plant populations under regeneration could be geographically extensive and, eventually, lead to long-lasting changes. Therefore, it is essential to understand how inter-annual variability in rainfall patterns and rainfall extremes, among other climatic conditions, affect post-fire regeneration.

Seeder species are common in Mediterranean areas (Trabaud, 1987; Bond and van Wilgen, 1996). These are species with all individuals dying during the fire, and that depend on post-fire germination for reestablishment. Therefore, they can be particularly sensitive to the vagaries of the weather and climate after fire. Germination is commonly triggered by the first rains (Quintana et al., 2004). However, temperature or other requirements for germination vary among species (Baskin and Baskin, 1998); hence, the temporal pattern of rainfall can shift the time of germination up to several months. Once germination has occurred, soil moisture is probably the most limiting factor for seedling survival (Moreno and Oechel, 1992). Seedling mortality during the first few months, up to and including the first summer, is very high (Moreno and Oechel, 1992; Thanos et al., 1996; Lloret, 1998; Quintana et al., 2004). Consequently, climatic conditions after fire can play a significant role in regulating germination and seedling mortality in these species. Differences in the sensitivity of germination or seedling survival to drought (and other features of post-fire climate) among coexisting species may lead to shifts in the structure and composition of plant populations.

Aside from the postfire climatic conditions, the number of seedlings emerging after fire is a function of the size and dormancy state of the soil seed-bank in interaction with fire intensity and severity. Soil seed banks in Mediterranean ecosystems are persistent but fluctuate along the year and between years, although these changes have not been well quantified (Clemente et al., 2007). The size of the seed-bank will change during the course of the season, being highest in late summer and lowest in late spring, before seed maturation and dispersal (Bastida and Talavera, 2002; Traba et al., 2006). Therefore, the size of the soil seed-bank at the time of fire could vary depending on when fire occurs, and this could affect the number of germinates and subsequent recruits.

The objectives of this study were to assess how post-fire seedling emergence and recruitment of three seeder species varied following fires lit during three years and at two different times (early and late) within the fire season. The questions addressed were: how variable are seedling emergence and recruitment following burning in different years? Is this variability related to the rainfall following fire? How does fire season interact with the previous factors? By burning during several years and at two times during the fire season, we intended to assess the variability in emergence and recruitment through the years, and to cover a period within which a large fluctuation in the soil seed-bank was likely to occur. By allowing a long period of time between burns, we aimed at understanding the impacts on plant populations of fires that could occur at different times during the year. This is important under the ongoing and projected changes in climate for the Mediterranean. Increased temperature, reduced total precipitation and changes in rainfall patterns (Christensen et al., 2007) are projected to lengthen the fire season (Moriondo et al., 2006; Moreno et al., 2010), hence, making fires to potentially occur earlier and later during the year.

\section{Materials and methods}

The study was carried out at the Coto Nacional de los Quintos de Mora (Los Yébenes, Toledo, $39^{\circ} 23^{\prime} \mathrm{N}, 4^{\circ} 00^{\prime} \mathrm{W}$ ). The climate is Mediterranean. Long-term mean yearly temperature is $14.6^{\circ} \mathrm{C}$ and mean precipitation is $683 \mathrm{~mm}$, of which only $13.2 \%$ falls during the summer months (JuneSeptember; data from Los Cortijos meteorological observatory, located $10 \mathrm{~km}$ away from the site). An old ( $>45$ years) shrubland stand was chosen in a south-facing slope, $17 \%$ inclination, at $900 \mathrm{~m}$ elevation. The shrubland was dominated by Cistus ladanifer L., Erica arborea L., Erica umbellata Loefl. ex L., Phillyrea angustifolia L. and Rosmarinus officinalis L. (Table 1). Other less abundant species were Erica scoparia L. and Arbutus unedo L., but these shall not be further considered. Plant abundance (density and basal area of live and dead stems) was estimated in twenty $1 \times 1 \mathrm{~m}$ located along two $10 \mathrm{~m}$ transects set in each plot (see below). Cover was visually estimated in an adjacent stand, in six hundred $0.5 \times 0.5 \mathrm{~m}$ quadrats. Cistus ladanifer, Erica umbellata and Rosmarinus officinalis (Cistus, Erica and Rosmarinus from here on), are non-sprouting seeders, i.e. all plants die after fire, and recruitment is dependent on germination. Phillyrea resprouts from underground producing several stems. It is not possible to differentiate at the surface whether they all originate from the same individual. Thus, we assumed all shoots close to one another conformed one individual. Erica arborea and Phillyrea angustifolia are resprouters. Emergence of these two species was nil during the study period and will not be treated further.

During three consecutive years (Yr 1 to Yr 3; we set the years to start in October, coinciding with the end of the fire season, and end in September of the next year), experimental burns (B1, B2 and B3) were conducted early (late June) and late (end of September/beginning of October) in the fire season (ES and LS, respectively). At each burn, 3 plots $(13 \times 14 \mathrm{~m})$ were burned, adding up to 18 plots in total ( 3 years $\times 2$ seasons $\times 3$ replicates; Fig. 1 ). Fires were conducted by burning up-hill and downwind. All three plots per season and year were burned during the same day. Burning 
Table 1. Mean (range) plant density and stem basal area of live, dead and live+dead individuals in all 18 plots prior to being burned at the Coto Nacional de Quintos de Mora, central Spain. Cover was visually estimated in an adjacent stand (see Methods section).

\begin{tabular}{|c|c|c|c|c|c|c|c|}
\hline \multirow{2}{*}{ Species } & \multicolumn{3}{|c|}{ Density (Ind. $\mathrm{m}^{-2}$ ) } & \multicolumn{3}{|c|}{ Stem basal area $\left(\mathrm{cm}^{2} \mathrm{~m}^{-2}\right)$} & \multirow{2}{*}{$\begin{array}{c}\text { Cover } \\
(\%)\end{array}$} \\
\hline & Live & Dead & Live + Dead & Live & Dead & Live + Dead & \\
\hline Cistus ladanifer & $2.19(2.58-1.85)$ & $2.06(2.48-1.68)$ & $4.25(4.93-3.82)$ & $7.03(9.99-5.55)$ & $7.90(11.58-5.85)$ & $14.93(21.58-12.31)$ & 35.1 \\
\hline Erica umbellata & $0.69(1.17-0.37)$ & $0.67(1.48-0.37)$ & $1.36(2.65-0.82)$ & $0.94(1.68-0.51)$ & $0.96(1.27-0.60)$ & $1.90(2.73-1.11)$ & 15.1 \\
\hline Rosmarinus officinalis & $0.47(0.57-0.17)$ & $0.18(0.25-0.13)$ & $0.65(0.82-0.38)$ & $1.49(3.43-0.39)$ & $1.27(3.88-0.51)$ & $2.76(7.31-1.03)$ & 8.3 \\
\hline Phillyrea angustifolia & $3.66(7.37-1.47)$ & $0.59(1.70-0.03)$ & $4.24(9.07-1.60)$ & $5.30(6.49-4.50)$ & $0.90(1.15-0.50)$ & $6.20(7.60-4.99)$ & 32.3 \\
\hline Erica arborea & $1.50(2.02-1.18)$ & $0.54(0.97-0.32)$ & $2.04(2.42-1.55)$ & $7.11(8.28-4.30)$ & $2.99(4.60-2.14)$ & $10.10(12.79-6.98)$ & 24.1 \\
\hline
\end{tabular}

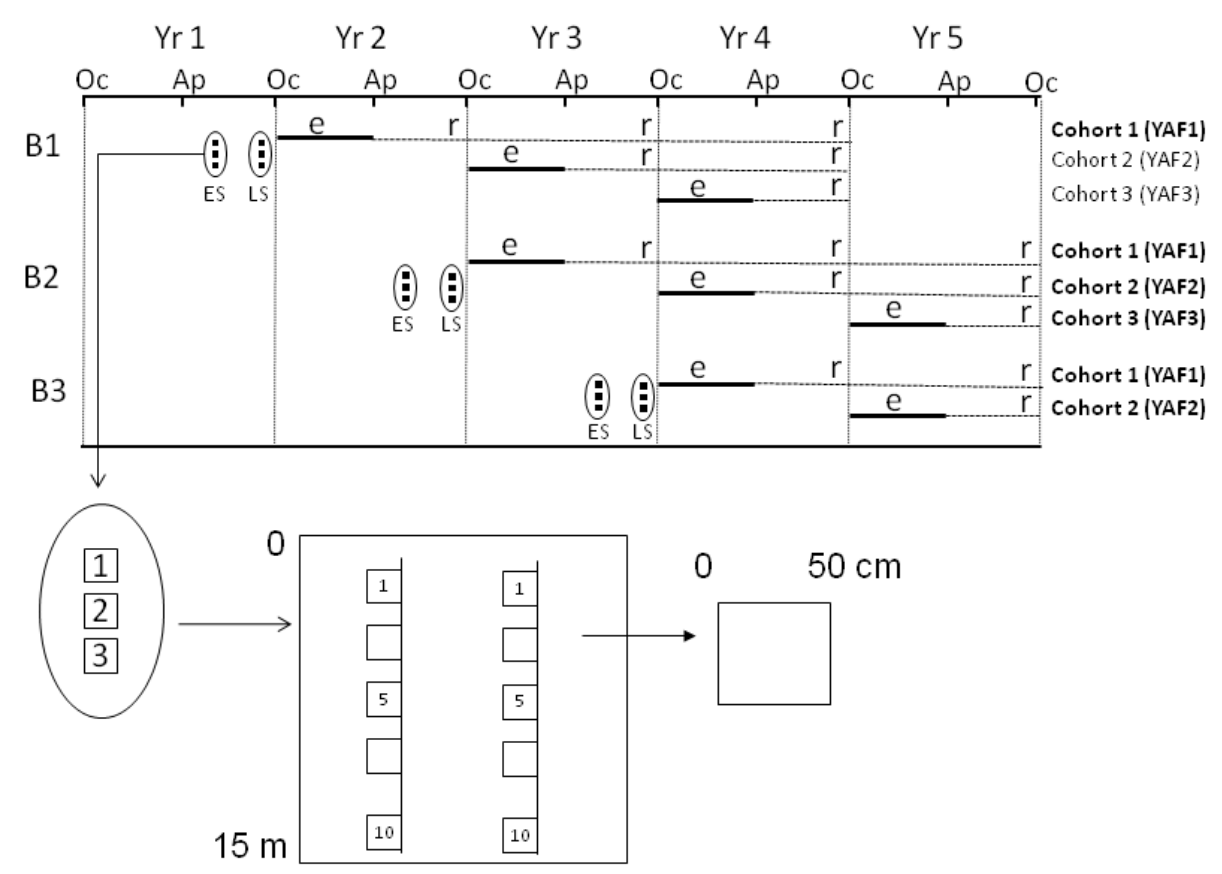

Fig. 1. Scheme of the experimental design and timing of experimental burning and postfire monitoring of emergence (e) and recruitment (r). The experiment took place during five consecutive years. Experimental burning took place during each of the first three years (B1 to B3) in late June (ES) or late September/early October (LS) (3 plots per burning, for a total of 18 plots). Seedling emergence was monitored monthly during relevant periods (fall to spring) in twenty $0.50 \times 0.50 \mathrm{~cm}$ permanent quadrats. Recruitment was monitored at regular intervals, particularly at the end of summer. Seedlings emerged after fires were separated by cohorts based on their year after fire of emergence. The first three burns were monitored during three years, the last burn only during two. The cohorts that had a relevant number of seedlings are marked in bold. Note that YAF (year after fire) refers to each particular burn.

was always conducted on clear, sunny days, and under stable conditions. Except in the first set of burns (B1 ES), soil surface temperatures during fire were recorded with 10$15 \mathrm{~K}$-type thermocouples placed $1 \mathrm{~cm}$ above the soil surface, and connected to a data logger (Campbell Scientific, Logan, Utah, USA). From this, we calculated the time-temperature integral, which can be a good estimation of the total heat reaching the soil surface during fire, hence of fire-intensity (Keeley, 2009).

The Coto Nacional de los Quintos de Mora has been used for game hunting for decades, and herbivore stocks are kept at much higher rates than would be normal. To avoid tram- pling and herbivory by large mammals, the whole area was fenced before the first fire. In each plot, two $10 \mathrm{~m}$ transects were established, and along each, ten $50 \times 50 \mathrm{~cm}$ quadrats were permanently set at regular intervals. These were used to monitor post-fire seedling emergence and survival. After fire, emergence and establishment were monitored regularly at monthly intervals (during active periods of seedling emergence). Emerged seedlings were tallied, tagged and monitored during the three following years, except for the last set of burns (B3) in which post-fire monitoring lasted only two years (Fig. 1). Therefore, seedling monitoring after fire lasted four years (Yr 2 to Yr 5). B1 burns were conducted in 

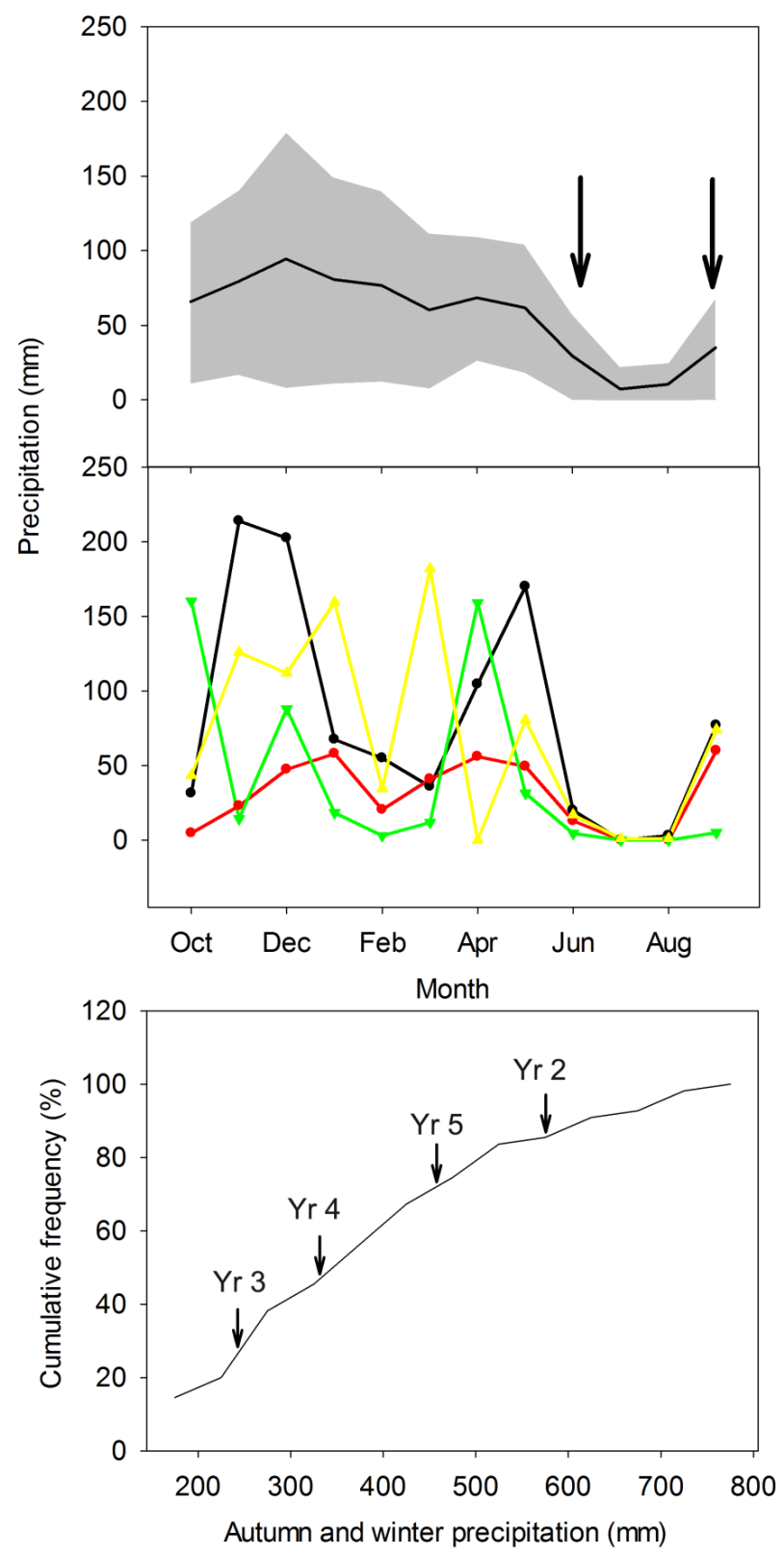

Fig. 2. (a) Mean (line) and standard deviation (shaded area) of monthly precipitation during 40 years of observations at Los Cortijos meteorological observatory. Arrows indicate when burnings were conducted. (b) Precipitation during the four years of postfire monitoring: Yr 2, black; Yr 3, red; Yr 4, green; Yr 5, yellow. (c) Cumulative frequency distribution of winter and fall precipitation (October through February), with arrows indicating the amount of precipitation of each year.

the fire season of Yr 1, and were monitored from the beginning of Yr 2 to the end of Yr 4. B2 burns were conducted in the fire season of $\mathrm{Yr} 2$, and were monitored during $\mathrm{Yr} 3$ to Yr 5. B3 burns were conducted in the fire season of $\mathrm{Yr} 3$, and were monitored during Yr 4 and Yr 5. Seedling emergence after fire occurred during a maximum of three years (B2), and was differentiated by yearly cohorts based on the year-afterfire (YAF) of emergence (cohort 1 to cohort 3). Since burning was done in consecutive years, different cohorts overlapped over the years (Fig. 1).

Homogeneity in initial conditions across plots (in live, dead, and live+dead plant density and stem basal area for the different species) was assessed with non-parametric KruskalWallis tests, due to heterocedascity of variances even after transformations. Differences in seedling emergence (emergence at the end of YAF1 and YAF2) and recruitment (total seedling density at the end of YAF1 or YAF2) in relation to burning year, fire season and year-after-fire were analyzed by repeated measures ANOVA. There were two betweensubjects factors and one within-subject factor, with three replicates for each treatment combination. Between subjects factors were burning year (B1, B2, and B3; $n=3$ ) and fire season (ES and LS; $n=2$ ). The within-subject factor was the year-after-fire (YAF1 and YAF2) at which emergence or recruitment was recorded. Finally, differences in the timetemperature integral between burning year and fire season were analyzed by a two-way ANOVA for B2 and B3 burns.

To understand trends in recruitment and the factors controlling them, we compared recruitment at the end of YAF2 with emergence during YAF1 for each burn by linear regression $(n=6$, that is, each point was the mean of the three plots burned per season each year). Similarly, we compared recruitment at the end of YAF3 with recruitment at the end of YAF2 for B1 and B2 burns ( $n=4$; B3 burns could not be included since YAF3 was not sampled in these burns). Differences in the slope of these relationships among species were examined by the ratio of the difference in slopes to the standard error of the difference between slopes. Finally, seedling emergence at the end of YAF1 was related to rainfall during fall and winter (October through February) of that year for each of the burns by ordinary least square linear regression. Statistical analyses were conducted with SPSS vs. 13 (SPSS Inc., Somers, NY) and R (R Development Core Team, 2011).

\section{Results}

The characteristics of the stands chosen were: Cistus was the dominant species among the three seeders, followed by Erica umbellata and Rosmarinus. Rosmarinus was larger in size, and in terms of stem basal area was second to Cistus. Among the resprouters, Phillyrea had greater density, but lower stem basal area than Erica arborea (Table 1). No statistically significant differences $(p>0.05)$ were observed for any of the density measurements (live, dead or live+dead) across plots before burning for all species except Phillyrea, in which the three measures of density were significantly different among years $(p=0.040,0.007,0.025$ for live, dead and live+dead density, respectively), but not among seasons ( $p>0.05$ in all three cases). Stem basal area measurements for all three categories (live, dead, live + dead) and all five 


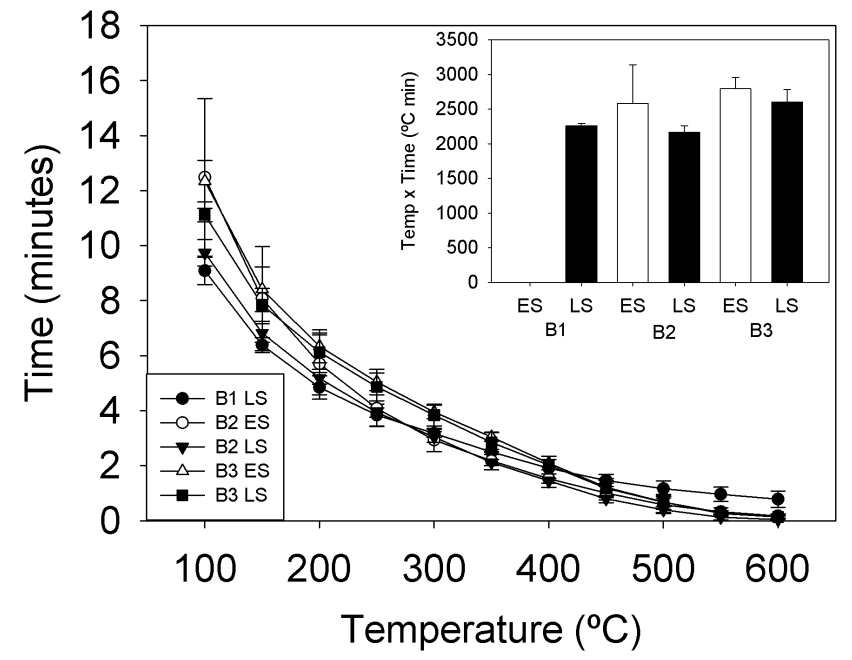

Fig. 3. Residence time of temperatures from $100^{\circ} \mathrm{C}$ to $600{ }^{\circ} \mathrm{C}$ during experimental burns early (ES) and late (LS) in the fire season and in each of the three consecutive burning years (B1 to B3). Inset figure shows the means and standard errors for the temperaturetime integral (in ${ }^{\circ} \mathrm{C}$ min). Temperature for the B1 ES burns was not available.

species were not significantly different for either years or seasons $(p<0.05)$.

Annual precipitation during the four years of seedling monitoring (Yr 2 to Yr 5) was highly variable, and covered a large portion of the long-term variability observed in the area (Fig. 2). Rainfall in Yr 2 and Yr 5 were above the long-term mean, while rainfall in Yr 4 and, particularly, during Yr 3 were well below average (Fig. 2). Soil surface temperatures during the experimental burns were similar between burning years and seasons (Fig. 3). There were no statistically significant differences for time-integrated temperature during fires (burning year: $F_{2,10}=1.59, p=0.25$; season: $F_{1,10}=2.25$, $p=0.16$; burning year $x$ season: $F_{1,10}=0.40, p=0.54$ ).

There were large differences in total emerged seedlings between years and species. Cistus was the species with the greatest average seedling emergence during the three burning years, varying between burns by a factor greater than 3 (from 61 to 204 seedlings $\mathrm{m}^{-2}$ ). Erica produced, on average, the second largest emergence; yet, its variability between burns was much larger (factor of 12, from 13 to 156 seedlings $\mathrm{m}^{-2}$ ). Rosmarinus was the species with fewer seedlings emerged on average, and with lesser variability among burns (factor of 3, from 6 to 17 seedlings $\mathrm{m}^{-2}$; Fig. 4). Burning year was a statistically significant factor for emergence in Cistus, and Erica and non-significant in Rosmarinus (Table 2; Online Supplementary Material 1).

Seedling emergence during the subsequent years after fire (cohort 1 to cohort 3 ) changed depending on the burning year and species. Emergence following B1 burns occurred in one single cohort (cohort 1) for all three species (Fig. 4).
Table 2. Main effects and interactions of the repeated measures ANOVA for burning year (Year), fire season (Season) and year after fire (YAF)(the first two years) on emergence and recruitment of three seeder species growing in a Mediterranean shrubland in central Spain. Burning year and fire season were between subject factors, and year after fire was a within subject factor. Species were: Cistus ladanifer (Cistus), Erica umbellata (Erica) and Rosmarinus officinalis (Rosmarinus). $N=3$ plots per fire season and year.

\begin{tabular}{|c|c|c|c|c|}
\hline & \multicolumn{2}{|c|}{ Emergence } & \multicolumn{2}{|c|}{ Recruitment } \\
\hline & $F$ & $p$ & $F$ & $p$ \\
\hline \multicolumn{5}{|l|}{ Cistus } \\
\hline YAF & 188.48 & $<0.001$ & 2.09 & 0.17 \\
\hline Year & 5.27 & 0.02 & 2.70 & 0.11 \\
\hline Season & 12.01 & $<0.01$ & 3.30 & 0.09 \\
\hline Year $\times$ Season & 5.22 & 0.02 & 2.56 & 0.12 \\
\hline YAF $\times$ Year & 7.90 & $<0.001$ & 0.24 & 0.79 \\
\hline YAF $\times$ Season & 120.60 & $<0.001$ & 0.20 & 0.67 \\
\hline YAF $\times$ Year $\times$ Season & 30.46 & $<0.001$ & 0.21 & 0.82 \\
\hline \multicolumn{5}{|l|}{ Erica } \\
\hline YAF & 12.20 & $<0.01$ & 0.10 & 0.75 \\
\hline Year & 3.79 & 0.05 & 2.91 & 0.09 \\
\hline Season & 0.57 & 0.46 & 1.25 & 0.28 \\
\hline Year $\times$ Season & 0.43 & 0.66 & 0.68 & 0.52 \\
\hline YAF $\times$ Year & 3.85 & 0.05 & 4.55 & 0.03 \\
\hline YAF $\times$ Season & 0.00 & 0.98 & 0.40 & 0.54 \\
\hline YAF $\times$ Year $\times$ Season & 1.87 & 0.20 & 1.95 & 0.18 \\
\hline \multicolumn{5}{|l|}{ Rosmarinus } \\
\hline YAF & 56.94 & $<0.001$ & 8.20 & 0.01 \\
\hline Year & 2.76 & 0.10 & 2.14 & 0.16 \\
\hline Season & 0.73 & 0.41 & 0.26 & 0.62 \\
\hline Year $\times$ Season & 0.11 & 0.90 & 0.02 & 0.98 \\
\hline YAF $\times$ Year & 36.82 & $<0.001$ & 1.80 & 0.21 \\
\hline YAF $\times$ Season & 14.23 & $<0.01$ & 1.84 & 0.20 \\
\hline YAF $\times$ Year $\times$ Season & 7.88 & $<0.01$ & 0.07 & 0.93 \\
\hline
\end{tabular}

However, emergence after B2 burns occurred over the next three years (cohort 1 to 3 ). Similarly, emergence following B3 burns occurred over the next two years after fire (the third year could not be sampled). Emergence was generally highest in YAF1 (larger size of cohort 1) than in YAF2 or YAF3 (lower size of cohorts 2 and 3, if at all present) for all burning years, but with differences among species (Fig. 4). For instance, emergence in Erica was higher in YAF2 (cohort 2) than in YAF1 (cohort 1) for two burning years (B2 and B3). Actually, in one occasion (B2, LS) emergence in YAF3 (cohort 3) was even higher than in YAF1 (cohort 1) (Fig. 4). Year-after-fire (YAF1 and YAF2 were the only two tested; see Methods) was a significant factor for the three species. Furthermore, there was a significant interaction between YAF and burning year for all three species, and with season for Cistus and Rosmarinus (Table 2). In absolute figures, LS burns produced greater emergence than ES burns 

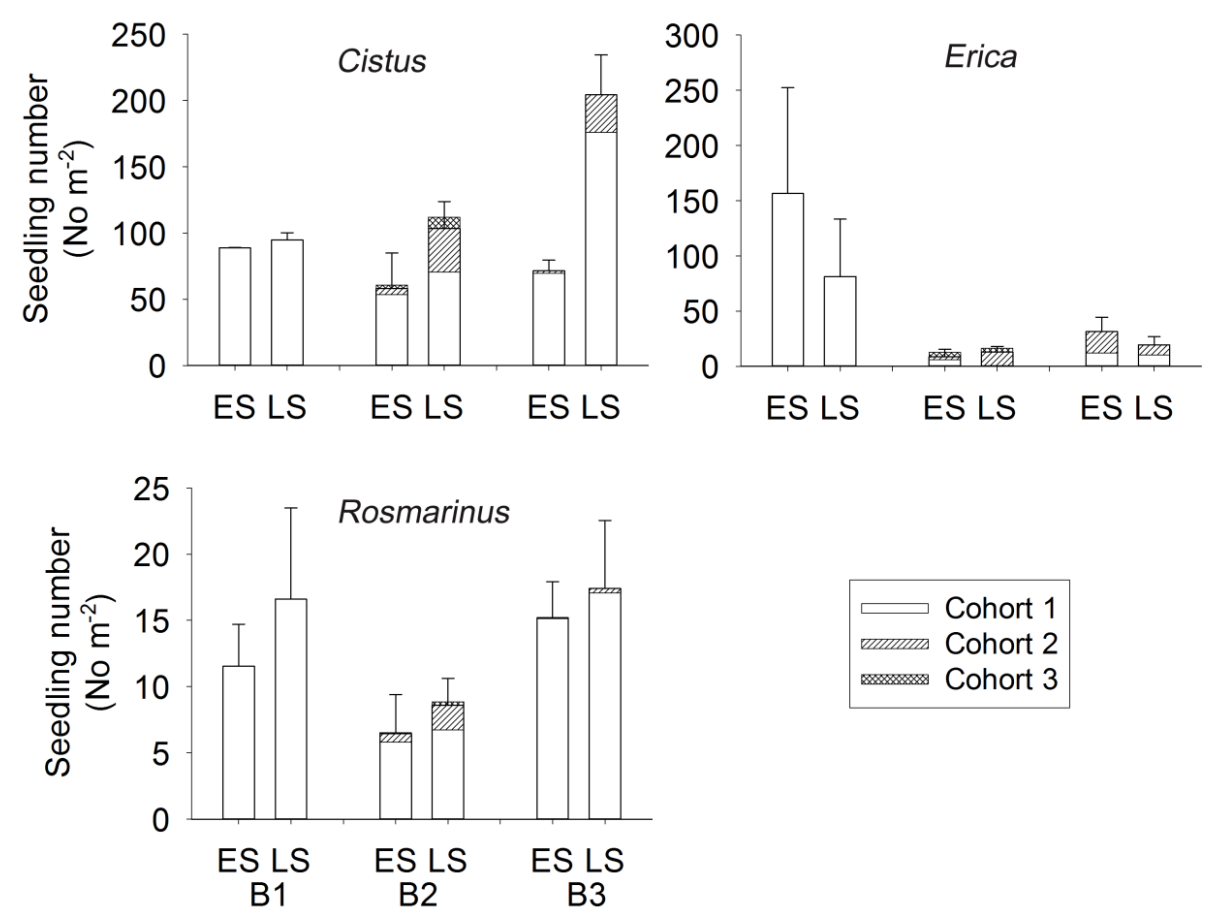

Fig. 4. Seedling emergence of three seeder species (Cistus ladanifer, Erica umbellata and Rosmarinus officinalis) after experimental burning early (ES) and late (LS) in the fire season during three consecutive years (B1, B2 and B3 burns) at a shrubland in Central Spain. Shown are total seedling emergence during the first (cohort 1), second (cohort 2) and third (cohort 3) year after fire. Note that B3 burns were monitored only during two years. Error bars refer YAF2 data, which were used in the statistical tests (see Methods).

for Cistus and Rosmarinus, while the opposite pattern was seen in Erica (Fig. 4). Nevertheless, season was a statistically significant factor only for Cistus. Furthermore, season in this species interacted with burning year and YAF, respectively (two way interaction) and jointly with the two (three way interaction; Table 2).

At the end of the third year after fire (second for B3 burns) recruitment for the three species showed similar patterns to total seedling emergence. Note that the population of recruiters of Cistus and Rosmarinus was mainly composed of cohort 1 individuals (Fig. 5). That was not so for Erica, with a recruiter population composed by individuals that had germinated in the first, second or even third year after fire, depending on the burning year (Fig. 5; Supplementary Material 1). Few effects, however, were significant in recruitment: burning year was marginally significant $(p<0.1)$ in Erica, with a significant interaction with YAF. Season was also marginally significant for Cistus. YAF was only a significant factor for Rosmarinus recruitment (Table 2). That is, recruitment in YAF1 was different from that in YAF2 for Rosmarinus, while no differences were observed in the recruitment of Cistus or Erica across YAF. Recruitment at the end of the second year after fire was tightly correlated with seedling emergence during the first year after fire in the three species (Fig. 6). Note the high $R^{2}$ of the models, particularly in Cistus and Rosmarinus. The slopes of these regres- sions were significantly different $(p \leq 0.05)$ among the three species, being highest in Rosmarinus (0.36) (higher recruitment in relation to emergence), intermediate in Cistus (0.24) and lowest in Erica (0.09) (the lower the slope the lower recruitment, that is, survival in relation to emergence). Furthermore, recruitment at the end of the third year after fire was virtually the same than at the end of the second year for Rosmarinus and Cistus (we observed an intercept and a slope statistically identical $(p>0.05)$ to 0 and 1 , respectively). However, the slope of the relationship between third and second year recruitment in Erica was 0.44 and significantly $(p<0.05)$ smaller than 1 . This indicates that recruitment in Erica decreased from the second to the third year after fire (Fig. 7). There was a significant relationship between the amount of rain fallen in autumn and winter (October through February) the first year after fire and emergence during that year for Rosmarinus and, particularly, for Erica but not for Cistus (Fig. 8).

\section{Discussion}

\subsection{Event-dependent processes and population changes}

Seedling emergence and recruitment across years and seasons for the three species studied was highly variable; this variability was species-dependent and different between 

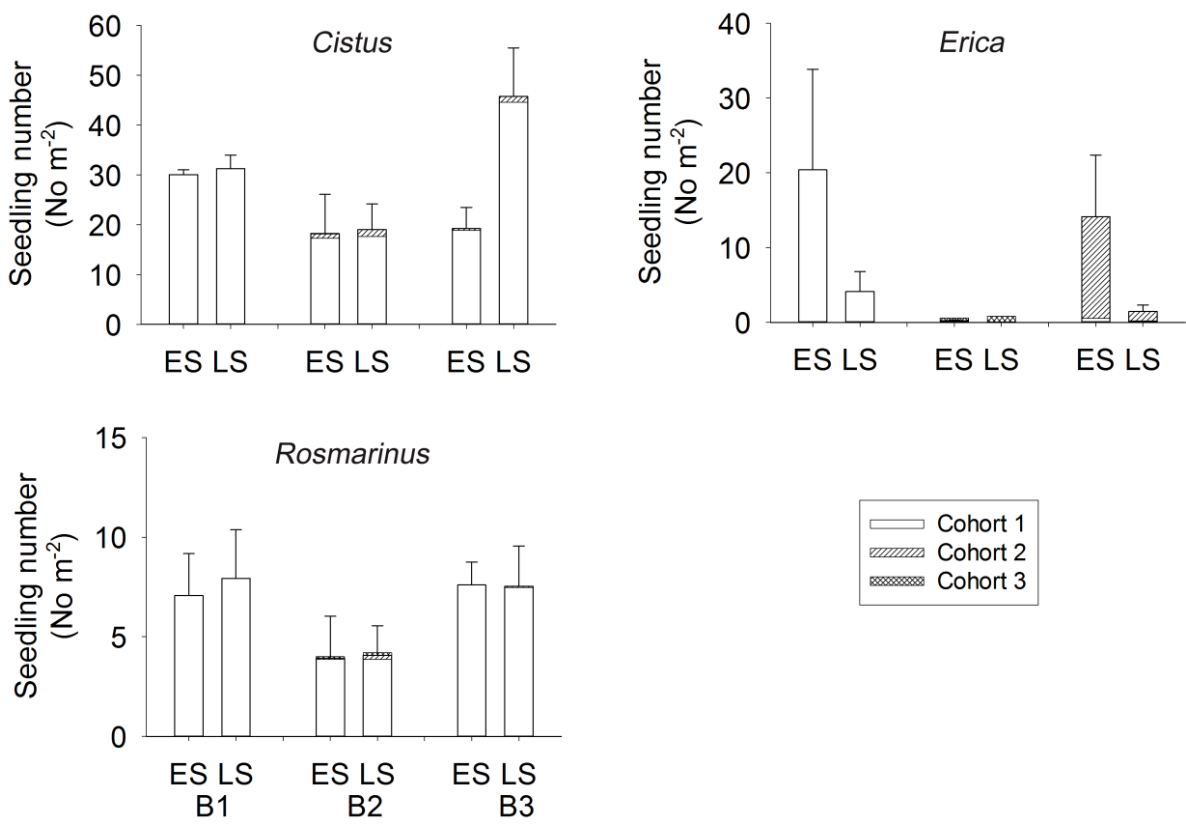

Fig. 5. Recruitment (No. $\mathrm{m}^{-2}$ ) at the end (three years for $\mathrm{B} 1$ and $\mathrm{B} 2,2$ years for $\mathrm{B} 3$ ) for three seeder species (Cistus ladanifer, Erica umbellata and Rosmarinus officinalis) after experimental burning early (ES) or late (LS) during the fire season during three consecutive years (B1, B2 and B3 burns) in a shrubland in Central Spain. Recruitment is shown distinguishing among the cohorts that germinated during the first (cohort 1), second (cohort 2) and third (cohort 3) year after fire. Error bars refer to YAF2 data, which were used in the statistical tests (see Methods)

emergence and recruitment. Temporal (across years and seasons) variation in seedling emergence was lowest in Rosmarinus, intermediate in Cistus, and highest in Erica. Interspecific differences in recruitment were also apparent, and they were largely related to emergence during the first year. This close relationship between emergence and recruitment indicates that the potential for variation in the population of recruits from year to year can be important, depending on what happens during the first year after fire. Because not all three species responded equally across the years and seasons, this means that the population of recruits of each species will vary depending on the particularities of time of fire and the postfire climatology, and that differences among species can appear as a result of fire. This supports the hypothesis that "event dependent" processes can be a cause of population changes in seeder dominated shrublands, such as the one studied here. This is relevant because it implies that, after a given fire, changes, that are difficult to anticipate, might occur in the demographics of the seeder species.

\subsection{Emergence, recruitment and rainfall}

This study documents that emergence and recruitment patterns were closely related to changes in postfire rainfall, and that this relationship varied by species. Rainfall during autumn and winter (October through February) of the first year after fire was an important factor in determining emergence and, ultimately, recruitment in the three species. The postfire yearly patterns of emergence in these species were closely related to rainfall patterns. In the burning year that was followed by a wet fall and winter (B1 burns), emergence was highest in all three species and occurred only during the first postfire year (basically, one single yearly cohort). By contrary, when the first year after fire was dry (B2 burns), the three species responded with a similar pattern of reduced emergence, and this was delayed until the next two years. Indeed, three yearly cohorts contributed to recruitment in all three species, in particular in Erica. Furthermore, despite a general effect of rainfall on post-fire emergence, the magnitude and ultimate significance of the change on the population of recruiters was species-dependent. Similar responses were found in experimental manipulations of drought (Lloret et al., 2004). This indicates that anticipating the impact of future changes in precipitation in these systems will be complicated until some generalities among species can be found.

It is important to note that $\operatorname{Yr} 2$ and $\mathrm{Yr} 3$ were at the extreme (46\% above and $60 \%$ below average OctoberFebruary precipitation, respectively) sides of the long-term frequency distribution of rainfall in the area, which provided us with a good representation of the range of patterns of emergence and recruitment after fire that can be expected in this shrubland. The variability in demographic responses found here documents that studies based on single-year experiments in systems with high interannual rainfall variability may not represent the wide range of outcomes that might 


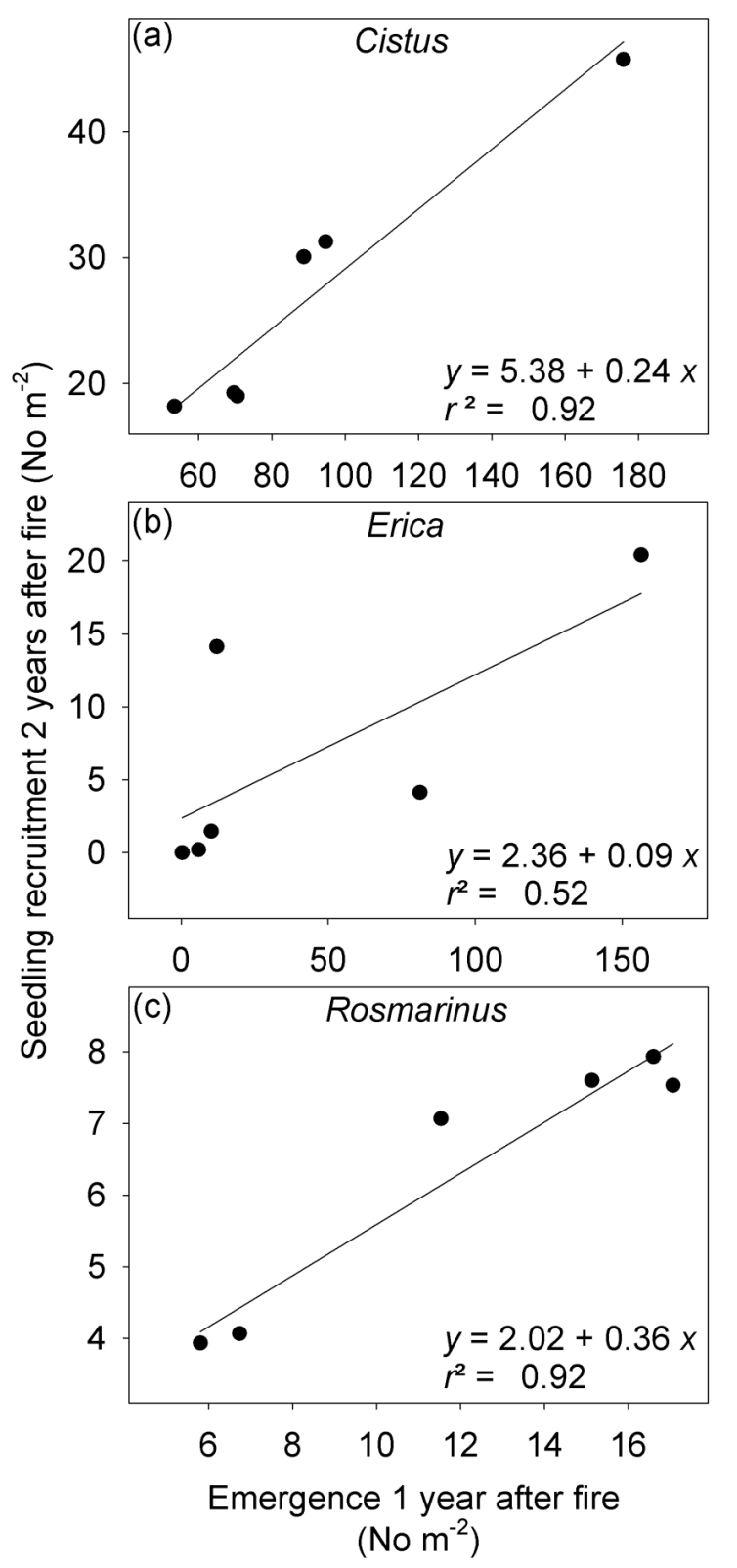

Fig. 6. Recruitment as a function of emergence one year after fire for Cistus ladanifer (a), Erica umbellata (b), and Rosmarinus officinalis (c). The line is the ordinary least squares best fit line. Each point is the mean of three plots in each year-by-season treatment.

occur across different years. Because rainfall variability after fire is important, using fire for management purposes entails a high degree of uncertainty, even if the system is well known in advance. While additional multiyear experiments are needed to have a better understanding of the interactions between fire season and changes in postfire climatology in Mediterranean shrublands, modelling can illustrate the longterm effects of these interacting factors (Bradstock and Bedward, 1992).

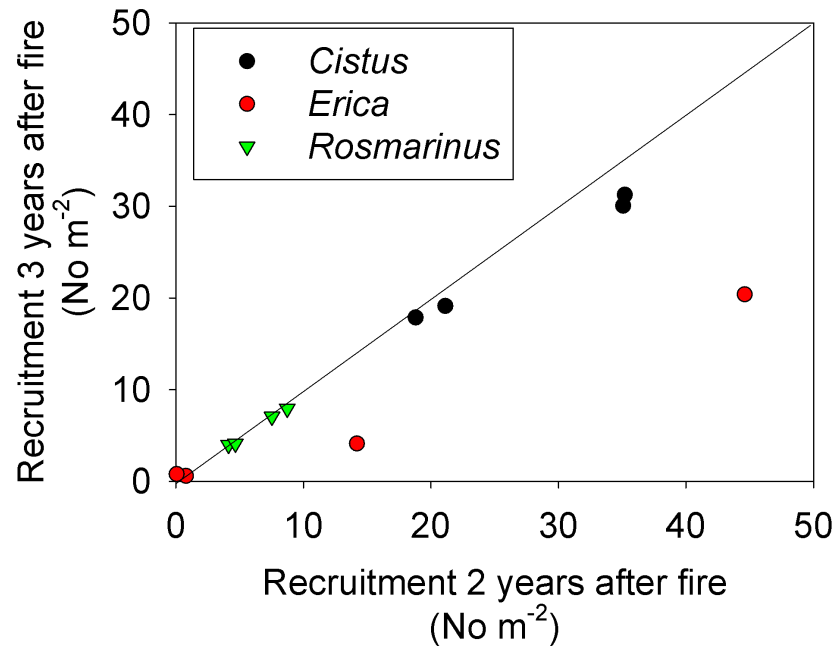

Fig. 7. Recruitment 3 years after fire as a function of recruitment 2 years after fire for three seeder species (Cistus, Erica and Rosmarinus). Note that while in Cistus and Rosmarinus the relationship lays along the 1-to-1 line, for Erica it lays below that line, indicating mortality of 2 yr-old recruiters during the third year after fire. Each point is the mean of three plots in each year-by-season treatment.

This study also documents that the window for recruitment of seeders after fire is virtually restricted to the first year after fire, as was found earlier at this site (Quintana et al., 2004), and also occurs on other Mediterranean systems (Keeley et al., 2005). Despite the differences in emergence patterns, the tight correlation between emergence on the first year and recruitment two or three years after fire indicates that individuals emerging after the first year will have a low probability of becoming recruits one or two years later. Consequently, what happens during the first year is vital, and rainfall in autumn-winter (October-February) appears as critical. This supports the hypothesis that early germination is favoured over spreading it over several years (Verdú and Traveset, 2005). This is important since many large fires and multiple large fire episodes occur under drought, and droughts can be long lasting (Lana et al., 2006). Consequently, the negative impact of a dry year following fire may not be compensated for in the following years, at least not equally in all species.

\subsection{Emergence, recruitment and fire season}

Despite variation among species, fire season was found not to be a strong factor in controlling seedling emergence and recruitment. This coincides with results reported by Trabaud and Lepart (1981), but contrasts to some extent with those of Céspedes et al. (2011) who observed that season was a significant factor for species like Rosmarinus. Several mechanisms can contribute to modify post-fire emergence in relation to fire season. First, fire season could affect fire intensity and interact with the physical dormancy of the seeds. Early season fires can occur when soils and plants have higher moisture 
content and thus will be of lower fire intensity than late season fires. Warming deeper into the soil might then be impeded and temperatures high enough to break the physical dormancy of seeds may not be reached (Hodgkinson, 1991). Not all seed species, however, require thermal scarification for germination and, in our case, this would only apply to Cistus (Thanos et al., 1992). Soils at the site were shallow, and seed density is usually highest in the upper soil layers $(2-3 \mathrm{~cm})$ (Clemente et al., 2007). Moreover, fire intensity was high and similar across burns and with burns in another similar shrublands (Céspedes et al., 2011). It thus seems unlikely that fire-intensity played a significant role in altering Cistus emergence.

Second, fires in different seasons may encounter differences in the size of the seed bank due to seed dispersal phenology. In the study area, Rosmarinus disperses from March to July; Erica disperses from July to October, with peak dispersal in August; Cistus has an extended period of seed dispersal, from July to January, with peak dispersal occurring also in August (Luna, 1998). Based on this, we expected that Rosmarinus would have had greater emergence in ES than in LS, as found by Céspedes et al. (2011), the reverse being true for the other two species. Nevertheless, only Cistus had significantly larger emergence in late season fires. Season was only marginally significant in recruitment at the end of the second postfire year. Aside from seed phenology, other factors such as seed predation (Bastida et al., 2009; Traba et al., 2006) or direct burn during the fire (Céspedes et al., 2011) can contribute to reducing the number of seeds in the soil seed bank, particularly those in the upper soil (Ferrandis et al., 1999; Valbuena et al., 2000). Third, seeds recently fallen might be physiologically dormant and their germination will be delayed until cold or other conditions have been met, provided suitable moisture is available. If rainfall is not sufficient after these conditions have been met, germination will be delayed until the next wet season (Ooi, 2010). This mechanism would not apply to Rosmarinus or Cistus, since both germinate readily after fire once the soil is moistened (Céspedes et al., 2011), but it could play a role in Erica. In this species, heat alone does not stimulate germination, but heat and cold stratification does, as well as smoke. Additionally, ash, with and without heat, completely deters germination of Erica (González Rabanal and Casal, 1995; Moreira et al., 2010). Germination after fire in the field is delayed in time with respect to the other two species; autumn rainfall triggering germination in Cistus and Rosmarinus was not as efficient for doing so in Erica, whose germination was delayed until later in the winter or spring (Quintana et al., 2004). Cold stratification is also required for germination in Erica australis, a species common in these shrublands (Trigueros Vera et al., 2010). Furthermore, germination after fire in this species can be delayed by several months (Valbuena et al., 2000). Therefore, we argue that, depending on rainfall patterns, dormancy might delay germination, so much that the effects of the current seed crop would not be

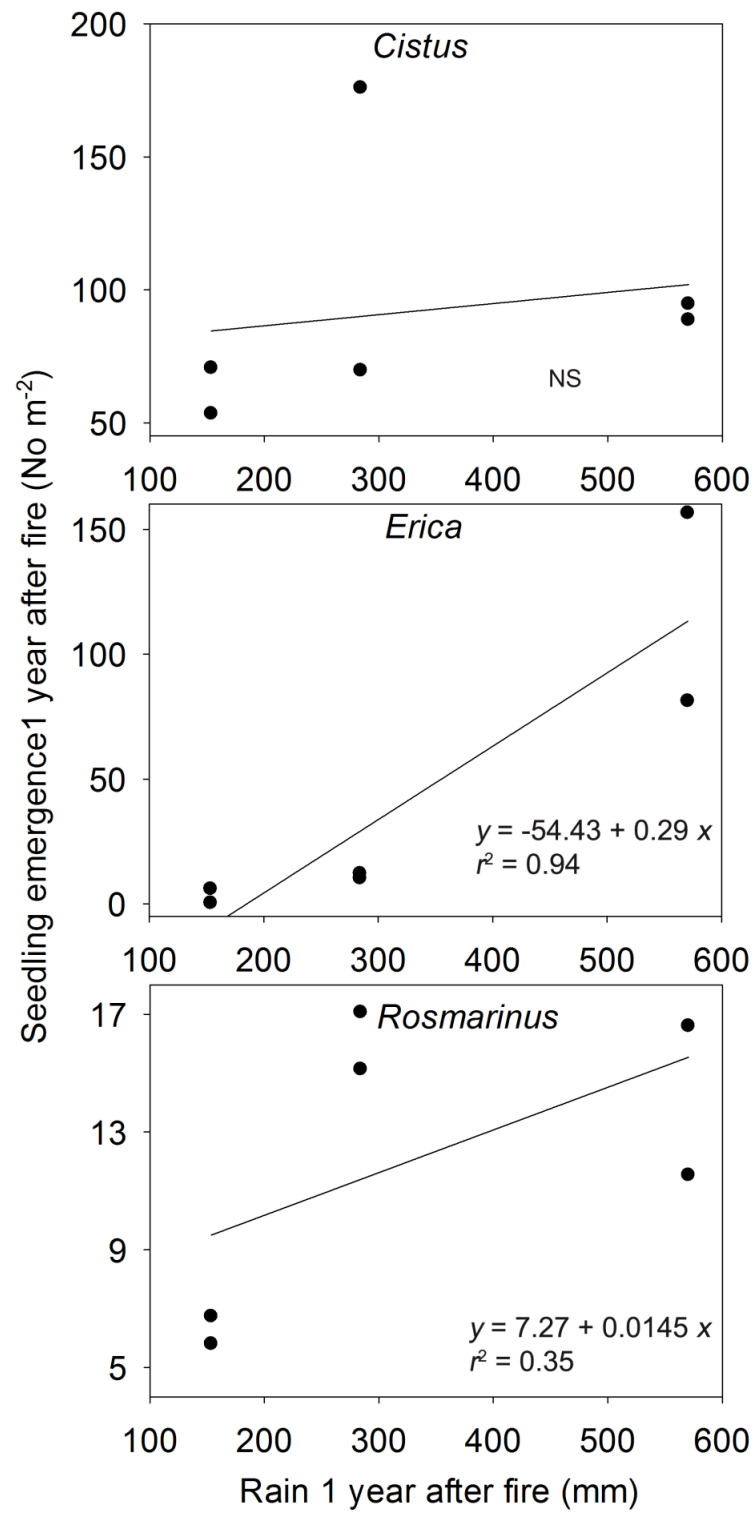

Fig. 8. Seedling emergence during the first year after fire as a function of autumn and winter (October through February) precipitation one year after fire for Cistus ladanifer (a), Erica umbellata (b), and Rosmarinus officinalis (c) after experimental burning. The line is the ordinary least squares best fit line (see Methods) and NS indicates a non-significant model. Each point is the mean of three plots in each year-by-season treatment.

so much detected after LS fires during the season of seed dispersal, but in the next year, once dormancy is broken. Ash could further contribute to delay germination until it has been leached from the soil. Although season was not a significant factor in Erica, it is worth noting that, contrary to seed dispersal patterns, in the two years with highest emergence, in absolute numbers this was higher in ES than in LS fires. Because Erica is an important component of western Iberian siliceous shrublands (Rivas-Martínez, 1979), further studies 
need to confirm whether dormancy alone or in combination with other factors plays a role in the fire season response pattern of this species. This is important because, if it does, the mixture of warmer winters and lower precipitation in spring in a future climate could impair the capacity of Erica to persist in these environments.

The pattern of demographic responses to fire season found in this study contrasts with results from systems with canopystored seed banks in either seasonal (Bond, 1984; Bond et al., 1984; Heeleman et al., 2008) or non-seasonal climates (Knox and Clarke, 2006), which usually find a strong fire-season effects on seedling populations. In such systems, dispersal follows fire; thus, seed predation during the period that elapses between fire and suitable conditions for germination will be very variable, depending on the timing of fire. The longer this period, the greater the negative impact on the size of the seed bank and subsequent seedling population.

\subsection{Implications in a context of climate change}

Our results show that emergence and recruitment in each species showed a slightly different response to fire and ensuing climatic conditions. Cistus emergence was sensitive to burning year and its recruitment marginally significant to season. In all cases, Cistus produced the largest number of seedlings, more than enough to replace the original population before fire. Cistus is a dominant species in acidic shrublands in the western Mediterranean, and dominates postfire environments. This supports the argument that this species is not vulnerable to changes in climatology or season of burning to maintain its population through fires. Rosmarinus showed low emergence rates, probably a reflection of its lower soil seed bank. However, it was the species with the highest relative recruitment success which suggests that its persistence through fires is not threatened. By contrary, Erica was sensitive to post-fire year, showing a substantial reduction in emergence and recruitment when dry post-fire conditions occurred. In one of the years recruitment was minimal, and below the replacement level. Cistus and Rosmarinus are distributed throughout much the Iberian Peninsula, and throughout a large range of annual precipitation. In contrast, the distribution of Erica is more restricted, and occurs where precipitation is higher. Indeed, the eastern limit of the distribution of Erica umbellata coincides roughly with the study site area (Benito Cebrián, 1948). Thus, Erica appeared as the most vulnerable species of the three to precipitation variability in the years following fire.

Climate models project an overall reduction in annual precipitation for the Mediterranean, with stronger reductions in summer precipitation than in winter precipitation (Giorgi and Lionello, 2008). Plant recruitment after fire was mainly driven by emergence, which in turn was related to autumnwinter precipitation, at least in Erica and Rosmarinus. This implies that rainfall is important for determining emergence, and suggests that summer drought might not be as critical for recruitment of seeder species after fire. Nevertheless, further studies need to confirm this, particularly if summer drought becomes more intense than what was experienced in this study. The results reported here for Erica were similar to those found in an experiment carried out several years earlier, and in which the first year after fire was also particularly dry (Quintana et al., 2004). These two studies document that Erica umbellata has great difficulty for recruiting after fire in a dry year. This leads us to argue that the persistence of this species can be seriously compromised in the case of fire and future reductions in rainfall, a trend that has been occurring in the Iberian Peninsula (Esteban-Parra et al., 1998), signalling a way by which these shrublands may lose species after climate change-induced changes in precipitation patterns.

\section{Supplementary material related to this article is available online at: http://www.biogeosciences.net/8/3721/2011/ bg-8-3721-2011-supplement.pdf.}

Acknowledgements. This project was funded in part by the CEAM (Project QUEMAS), and by the EC (EVG1-200100043). Writing benefited from funding by Caja de Guadalajara (Grant CONV080174 to JMM), and the European Social Fund (VRD). We thank the continuous support of the staff of the Coto Nacional de los Quintos de Mora. We dedicate this paper the memory of our colleague and friend Alberto Cruz.

Edited by: D. Zona

\section{References}

Baskin, C. M. and Baskin, J. M.: Seeds. Ecology, Biogeography, and Evolution of Dormancy and Germination, Academic Press, San Diego, 1998.

Bastida, F. and Talavera, S.: Temporal and spatial patterns of seed dispersal in two Cistus species (Cistaceae), Ann. Bot., 89, 427434, 2002.

Bastida, F., Talavera, S., Ortiz, P. L., and Arista, M.: The interaction between Cistaceae and a highly specific seed-harvester ant in a Mediterranean scrubland, Plant. Biol., 11, 46-56, 2009.

Benito Cebrián, N.: Brezales y brezos, Boletín Instituto Forestal de Investigaciones y Experiencias, 19, 5-67, 1948.

Bessie, W. C. and Johnson, E. A.: The relative importance of fuel and weather on fire behavior in subalpine forests, Ecology, 76, 747-762, 1995.

Bond, W. J.: Fire survival of Cape Proteaceae-influence of fire season and seed predators, Vegetatio, 56, 65-74, 1984.

Bond, W. J. and van Wilgen, B. W.: Fire and Plants. Chapman and Hall, London, 1996.

Bond, W. J., Vlock, J., and Viviers, M.: Variation in seedling recruitment of cape Proteaceae after fire, J. Ecol., 72, 209-221, 1984.

Bradstock, R. A. and Bedward, M.: Simulation of the effect of season of fire on fost-fire seedling emergence of two Banksia species based on long-term rainfall records, Australian Journal of Botany, 40, 75-88, 1992. 
Céspedes, B., Torres, I., Luna, B., Pérez, B., and Moreno, J. M.: Soil seed bank, fire season and temporal patterns of germination in a seeder-dominated Mediterranean shrubland, Plant Ecol., in press, doi:10.1007/s11258-011-9983-2, 2011.

Christensen, J. H., Hewitson, B., Busuioc, A., Chen, X., Gao, I., Held, R., Jones, R. K., Koli, W. T., Kwon, R., Laprise, V. M., Rueda, L., Mearns, C. G., Menéndez, J., Räisänen, A., Rinke, A., Sarr, A., and Whetton, P.: Regional climate projections, in: Climate Change, 2007: The Physical Science Basis, contribution of Working Group I to the Fourth Assessment Report of the Intergovernmental Panel on Climate Change, edited by: Solomon, S., Qin, D., Manning. M, Chen, Z., Marquis, M., Averyt, K. B., Tignor, M., and Miller, H. L., Cambridge University Press, Cambridge, 847-940, 2007.

Clemente, A. S., Rego, F. C., and Correia, O. A.: Seed bank dynamics of two obligate seeders, Cistus monspeliensis and Rosmarinus officinalis, in relation to time since fire, Plant Ecol., 190, 175188, 2007.

De Luis, M., Raventos, J., and González-Hidalgo, J. C.: Fire and torrential rainfall: effects on seedling establishment after fire in Mediterranean gorse shrublands, Int. J. Wildland Fire, 14, 413422, 2005

Esteban-Parra, M. J., Rodrigo, F. S., and Castro-Díez, Y.: Spatial and temporal patterns of precipitation in Spain for the period 1880-1992, Int. J. Climatol., 18, 1557-1574, 1998.

Ferrandis, P., Herranz, J. M., and Martínez-Sánchez, J. J.: Effect of fire on hard-coated Cistaceae seed banks and its influence on techniques for quantifying seed banks, Plant Ecol., 144, 103114, 1999.

Founda, D. and Giannakopoulos, C.: The exceptionally hot summer of 2007 in Athens, Greece - A typical summer in the future climate?, Global Planet. Change, 67, 227-236, 2009.

Giorgi, F. and Lionello, P.: Climate change projections for the Mediterranean region, Global Planet. Change, 63, 90-104, 2008.

González Rabanal, F. and Casal, M.: Effect of high temperature and ash on germination of ten species of gorse shrubland, Vegetatio, 116, 123-131, 1995.

Heelemann, S., Proches, E., Rebelo, A. G., van Wilgen, B. W., Porembski, S., and Cowling, R. M.: Fire season effects on the recruitment of non-sprouting serotinous Proteaceae in the eastern (bimodal rainfall) fynbos biome, South Africa, Austral Ecology, 33, 119-127, 2008.

Hodgkinson, K. C.: Shrub recruitment response to intensity and season of fire in semiarid woodland, J. A. Ecol., 28, 60-70, 1991.

Keeley, J. E.: Fire intensity, fire severity and burn severity: a brief review and suggested usage, Int. J. Wildland Fire, 18, 116-126, 2009.

Keeley, J. E., Fotheringham, C. J., and Baer-Keeley, M.: Determinants of postfire recovery and succession in Mediterraneanclimate shrublands of California, Ecol. Appl., 15, 1515-1534, 2005.

Keeley, J. E., Brennan, T., and Pfaff, H.: Fire severity and ecosystem responses following crown fires in California shrublands, Ecol. Appl., 18, 1530-1546, 2008.

Knox, K. J. E. and Clarke, P. J.: Fire season and intensity affect shrub recruitment in temperate sclerophyllous woodlands, Oecologia, 149, 730-739, 2006.

Lana, X., Martínez, M.D., Burgueño, A., Serra, C., Martín-Vide, J., and Gómez, L.: Distributions of long dry spells in the Iberian
Peninsula, years 1951-1990, Int. J. Climatol., 26, 1999-2021, 2006.

Lloret, F.: Fire, canopy cover and seedling dynamics in Mediterranean shrubland of northeastern Spain, J. Veg. Sci., 9, 417-430, 1998.

Lloret, F., Peñuelas, J., and Estiarte, M.: Experimental evidence of reduced diversity of seedlings due to climate modification in a Mediterranean-type community, Global Change Biology, 10, 248-258, 2004.

Luna, B.: Fenología y esfuerzo reproductivo de las especies arbustivas de un jaral-brezal del centro de la Península Ibérica, Tesina de Licenciatura, Madrid, 1998.

Moreira, B., Tormo, J., Estrelles, E., and Pausas, J. G.: Disentangling the role of heat and smoke as germination cues in Mediterranean Basin flora, Annals of Botany, 105, 627-635, 2010.

Moreno, J. M. and Oechel, W. C.: Fire intensity effects on germination of shrubs and herbs in southern California chaparral, Ecology, 72, 1993-2004, 1991.

Moreno, J. M. and Oechel, W. C.: Factors controlling postfire seedling establishment in southern California chaparral, Oecologia, 90, 50-60, 1992.

Moreno, J. M., Zavala, G., Martín, M., and Millán, A.: Forest fire risk in Spain under future climate change, in: Atlas of Biodiversity Risks, edited by: Settele. J., Penev, L., Georgiev, T., Grabaum, R., Grobelnik, V., Hammen, V., Klotz, S., Kotarac, M., and Kühn, I., Pensoft, Sofia and Moscow, 72-73, 2010.

Moriondo, M., Good, P., Durao, R., Bindi, M., Giannakopoulos, C., and Corte-Real, J.: Potential impact of climate change on fire risk in the Mediterranean area, Clim. Res., 31, 85-95, 2006.

Ooi, M. K. J.: Delayed emergence and post-fire recruitment success: Effects of seasonal germination, fire season and dormancy type, Aust. J. Botany, 58, 248-256, 2010.

Pausas, J. G., Ouadah, N., Ferran, A., Gimeno, T., and Vallejo, R.: Fire severity and seedling establishment in Pinus halepensis woodlands, eastern Iberian Peninsula, Plant. Ecol., 169, 205213, 2003.

Prieto, P., Peñuelas, J., Lloret, F., Llorens, L., and Estiarte, M.: Experimental drought and warming decrease diversity and slow down post-fire succession in a Mediterranean shrubland, Ecography, 32, 623-636, 2009.

Quintana, J. R., Cruz, A., Fernández-González, F., and Moreno, J. M.: Time of germination and establishment success after fire of three obligate seeders in a Mediterranean shrubland of Central Spain, J. Biogeogr., 31, 241-249, 2004.

$\mathrm{R}$ Development Core Team: A language and environment for statistical computing. R Foundation for Statistical Computing, Vienna, Austria, ISBN 3-900051-07-0, available at: http://www. R-project.org, 2011.

Rivas-Martínez, S.: Brezales y jarales de Europa occidental (Revisión Fitosociológica de las clases Calluno-Ulicetea y CistoLavanduletea), Lazaroa, 1, 5-128, 1979.

Thanos, C. A., Georghiou, K., Kadis, C., and Pantazi, C.: Cistaceae - a Plant family with hard seeds, Israel J. Bot., 41, 251-263, 1992.

Thanos, C. A., Daskalakou, E., and Nikolaidou, S.: Early postfire regeneration of a Pinus halepensis forest on Mount Párnis, Greece, J. Veg. Sci., 7, 273-280, 1996.

Traba, J., Azcárate, F. M., and Peco, B.: The fate of seeds in Mediterranean soil seed banks in relation to their traits, J. Veg. 
Sci., 17, 5-10, 2006.

Trabaud, L.: Fire and survival traits of plants, in: Role of Fire in Ecological Systems, edited by Trabaud, L., SPB Academic Publishing, The Hague, 65-89, 1987.

Trabaud, L. and Lepart, J.: Floristic changes in a Quercus coccifera $\mathrm{L}$. garrigue according to different fire regimes, Vegetatio, 46, 105-116, 1981.

Trigo, R. M., Pereira, J. M. C., Pereira, M. G., Mota, B., Calado, T. J., Da Camara, C. C., and Santo, F. E.: Atmospheric conditions associated with the exceptional fire season of 2003 in Portugal, Int. J. Climatol., 26, 1741-1757, 2006.
Trigueros Vera, D., Parra Martín, R., and Rossini Oliva, S.: Effect of chemical and physical treatments on seed germination of Erica australis, Annales Botanici Fennici, 47, 353-360, 2010.

Valbuena, L., Tárrega, R., and Luis-Calabuig, E.: Seed banks of Erica australis and Calluna vulgaris in a heathland subjected to experimental fire, J. Veg. Sci., 11, 161-166, 2000.

Verdú, M. and Traveset, A.: Early emergence enhances plant fitness: A phylogenetically controlled meta-analysis, Ecology, 86, 1385-1394, 2005. 